\title{
Management of 3rd and 4th Degree Perineal Tears after Vaginal Birth. German Guideline of the German Society of Gynecology and Obstetrics (AWMF Registry No. 015/079, October 2014)
}

Management von Dammrissen III. und IV. Grades nach vaginaler Geburt (S1-Leitlinie der Deutschen Gesellschaft für Gynäkologie und Geburtshilfe, AWMF-Registernumner 015/079, Oktober 2014)

Authors

Affiliations
T. Aigmueller ${ }^{1 *}$, W. Bader ${ }^{2 *}$, K. Beilecke ${ }^{3}$, K. Elenskaia ${ }^{4}$, A. Frudinger ${ }^{1}$, E. Hanzal ${ }^{4}$, H. Helmer $^{4}$, H. Huemer ${ }^{5}$, M. van der Kleyn ${ }^{6}$, D. Koelle ${ }^{7}$, S. Kropshofer ${ }^{8}$, J. Pfeiffer ${ }^{1}$, C. Reisenauer ${ }^{9}$, A. Tammaa ${ }^{10}$, K. Tamussino ${ }^{1}$, W. Umek ${ }^{4}$

The affiliations are listed at the end of the article.
Deutschsprachige Zusatzinformationen online abrufbar unter: www.thieme-connect.de/ ejournals/toc/gebfra
Bibliography

DOI http://dx.doi.org/

10.1055/s-0034-1396323

Geburtsh Frauenheilk 2015; 75:

137-144 @ Georg Thieme

Verlag KG Stuttgart · New York .

ISSN 0016-5751

\section{Correspondence}

Prof. Dr. med. Werner Bader Klinikum Bielefeld

Gynäkologie und Geburtshilfe

Teutoburger Straße 50

33604 Bielefeld

werner.bader@

klinikumbielefeld.de

PD Dr. med. Thomas Aigmüller Universitätsklinik für Frauenheilkunde und Geburtshilfe

Klinische Abteilung

für Gynäkologie

Auenbruggerplatz 14

8036 Graz

Österreich

thomas.aigmueller@

medunigraz.at

\section{Guideline Information}

Editor

Responsible Professional Society

German Society for Gynaecology and Obstetrics

(Deutsche Gesellschaft für Gynäkologie

und Geburtshilfe [DGGG] e.V.)

Head Office of DGGG and Professional Societies

Hausvogteiplatz 12

10117 Berlin

Tel.: + 49 (0) 30-514883340

Fax: + 49 (0) 30-514883344

info@dggg.de

http://www.dggg.de/

\section{President of the DGGG}

Prof. Dr. med. Diethelm Wallwiener

Universitätsfrauenklinik Tübingen

Calwerstraße 7

72076 Tübingen

\section{DGGG-Guideline Representative}

Prof. Dr. Matthias W. Beckmann

Universitätsklinikum Erlangen-Nürnberg

Frauenklinik

Universitätsstraße 21-23

91054 Erlangen

http://www.frauenklinik.uk-erlangen.de

\section{DGGG-Guideline Secretariat}

Dr. Paul Gaß, Tobias Brodkorb, Marion Gebhardt Universitätsklinikum Erlangen-Nürnberg

Frauenklinik

Universitätsstraße 21-23

91054 Erlangen

Tel.: + 49 (0) 9131-85/44063

or $+49(0) 9131-85 / 33507$

Fax: + 49 (0) 9131-85/33951

fk-dggg-leitlinien@uk-erlangen.de

http://www.dggg.de/leitlinienstellungnahmen/
Guideline group ( Tables 1 to 3 )

Table 1 Responsible and/or coordinating author.

$\begin{array}{ll}\begin{array}{ll}\text { Author } & \text { AWMF Professional Societies } \\ \text { Prof. Dr. } & \text { German Society for Gynaecology and } \\ \text { Werner Bader } & \text { Obstetrics (Deutsche Gesellschaft für } \\ & \text { Gynäkologie und Geburtshilfe } \\ & \text { DGGG), Consortium for Urogynaecol- } \\ & \text { ogy and Plastic Pelvic Floor Recon- } \\ & \text { struction (Arbeitsgemeinschaft für } \\ & \text { Urogynäkologie und plastische Beck- } \\ & \text { enbodenrekonstruktion AGUB) }\end{array} \\ & \begin{array}{l}\text { Austrian Urogynecology Working } \\ \text { PD Dr. }\end{array} \\ \begin{array}{l}\text { Thoma (Österreichische Arbeits- } \\ \text { Aigmüller }\end{array} & \begin{array}{l}\text { gemeinschaft für Urogynäkologie } \\ \text { und Rekonstruktive Beckenboden- } \\ \text { chirurgie AUB) }\end{array}\end{array}$

Financing

Financial support was not applied for. The experts were not paid for their work. All participants are hereby expressly thanked for the contributions.

Citation format

Management of 3rd and 4th Degree Perineal Tears after Vaginal Birth. German Guideline of the German Society of Gynecology and Obstetrics (AWMF Registry No. 015/079, October 2014). Geburtsh Frauenheilk 2015; 7: 137-144

\section{Guideline documents}

The editorially complete, long version of these guidelines as well as a summary of the conflicts of interest of all the authors can be found on the homepage of AWMF: http://www.awmf.org/leitlinien/detail/II/015-079.html.

* To be considered equally as first authors. 
Table 2 Further authors who participated in the guidelines.

\begin{tabular}{|c|c|}
\hline $\begin{array}{l}\text { Author } \\
\text { Mandate holder }\end{array}$ & DGGG Consortium (AG)/AWMF/non-AWMF-Professional Societies/Organisation/Association \\
\hline Dr. Katrin Beilecke & $\begin{array}{l}\text { German Society for Gynaecology and Obstetrics (Deutsche Gesellschaft für Gynäkologie und Geburtshilfe DGGG), } \\
\text { Consortium for Urogynaecology and Plastic Pelvic Floor Reconstruction } \\
\text { (Arbeitsgemeinschaft für Urogynäkologie und plastische Beckenbodenrekonstruktion AGUB) }\end{array}$ \\
\hline Dr. Ksenia Elenskaia & $\begin{array}{l}\text { Austrian Urogynecology Working Group } \\
\text { (Österreichische Arbeitsgemeinschaft für Urogynäkologie und Rekonstruktive Beckenbodenchirurgie AUB) }\end{array}$ \\
\hline Prof. Dr. Andrea Frudinger & $\begin{array}{l}\text { Austrian Urogynecology Working Group } \\
\text { (Österreichische Arbeitsgemeinschaft für Urogynäkologie und Rekonstruktive Beckenbodenchirurgie AUB) }\end{array}$ \\
\hline Prof. Dr. Engelbert Hanzal & $\begin{array}{l}\text { Austrian Urogynecology Working Group } \\
\text { (Österreichische Arbeitsgemeinschaft für Urogynäkologie und Rekonstruktive Beckenbodenchirurgie AUB) }\end{array}$ \\
\hline Prof. Dr. Hanns Helmer & $\begin{array}{l}\text { Austrian Urogynecology Working Group } \\
\text { (Österreichische Arbeitsgemeinschaft für Urogynäkologie und Rekonstruktive Beckenbodenchirurgie AUB) }\end{array}$ \\
\hline Dr. Hansjörg Huemer & $\begin{array}{l}\text { Austrian Urogynecology Working Group } \\
\text { (Österreichische Arbeitsgemeinschaft für Urogynäkologie und Rekonstruktive Beckenbodenchirurgie AUB) }\end{array}$ \\
\hline Moenie van der Kleyn & Austrian Midwives Committee (Österreichisches Hebammengremium) \\
\hline Dr. Dieter Kölle & $\begin{array}{l}\text { Austrian Urogynecology Working Group } \\
\text { (Österreichische Arbeitsgemeinschaft für Urogynäkologie und Rekonstruktive Beckenbodenchirurgie AUB) }\end{array}$ \\
\hline Dr. Stephan Kropshofer & $\begin{array}{l}\text { Austrian Urogynecology Working Group } \\
\text { (Österreichische Arbeitsgemeinschaft für Urogynäkologie und Rekonstruktive Beckenbodenchirurgie AUB) }\end{array}$ \\
\hline Prof. Dr. Johann Pfeifer & Austrian Society for Surgery (Österreichische Gesellschaft für Chirurgie [ÖGC]) \\
\hline Prof. Dr. Christl Reisenauer & $\begin{array}{l}\text { German Society for Gynaecology and Obstetrics (Deutsche Gesellschaft für Gynäkologie und Geburtshilfe DGGG), } \\
\text { Consortium for Urogynaecology and Plastic Pelvic Floor Reconstruction } \\
\text { (Arbeitsgemeinschaft für Urogynäkologie und plastische Beckenbodenrekonstruktion AGUB) }\end{array}$ \\
\hline Dr. Ayman Tammaa & $\begin{array}{l}\text { Austrian Urogynecology Working Group } \\
\text { (Österreichische Arbeitsgemeinschaft für Urogynäkologie und Rekonstruktive Beckenbodenchirurgie AUB) }\end{array}$ \\
\hline Prof. Dr. Karl Tamussino & $\begin{array}{l}\text { Austrian Urogynecology Working Group } \\
\text { (Österreichische Arbeitsgemeinschaft für Urogynäkologie und Rekonstruktive Beckenbodenchirurgie AUB) }\end{array}$ \\
\hline Prof. Dr. Wolfgang Umek & $\begin{array}{l}\text { Austrian Urogynecology Working Group } \\
\text { (Österreichische Arbeitsgemeinschaft für Urogynäkologie und Rekonstruktive Beckenbodenchirurgie AUB) }\end{array}$ \\
\hline
\end{tabular}

Table 3 Registered societies and consortiums with mandate holders.

\section{Mandate holder}

Prof. Dr. rer. medic. Rainhild Schäfers

Prof. Dr. Heiko Franz

Prof. Dr. Dr. Alexander Teichmann

Prof. Dr. Dietmar Schlembach

Prof. Dr. Birgit Seelbach-Göbel

Prof. Dr. Mathias Löhnert

Prof. Dr. Mathias Löhnert

PD Dr. Annette Kuhn

Dr. Ingrid Haunold

Dr. Uwe Lang

\section{Societies and working committees}

German Society for Midwife Science (Deutsche Gesellschaft für Hebammenwissenschaft)

Consortium for Materno-Foetal Medicine (Arbeitsgemeinschaft für materno-fetale Medizin e. V. [AGMFM])

Consortium for Medical Rights of the DGGG (Arbeitsgemeinschaft Medizinrecht der DGGG [AGMedR])

Consortium for Hypertension in Pregnancy/Gestosis (Arbeitsgemeinschaft Schwangerschaftshochdruck/ Gestose e.V.)

German Society for Prenatal and Neonatal Medicine (Deutsche Gesellschaft für Pränatal- und Geburtsmedizin [DGPM])

Surgical Consortium for Coloproctology in Germany (Chirurgische Arbeitsgemeinschaft Coloproktologie Deutschland [CACP])

German Society for Coloproctology (Deutsche Gesellschaft für Koloproktologie [DGK])

Swiss Consortium for Urogynaecology and Pelvic Floor Pathology (Schweizerische Arbeitsgemeinschaft für Urogynäkologie und Beckenbodenpathologie [AUG])

Consortium for Coloproctology in Austria (Arbeitsgemeinschaft für Coloproktologie Österreich [ACP])

Austrian Society for Gynaecology and Obstetrics (Österreichische Gesellschaft für Gynäkologie und Geburtshilfe [OEGGG])

\section{Abbreviations (@ Table 4)}

\section{Table 4 Abbreviations used.}

\begin{tabular}{ll} 
PT & Perineal Tear \\
OR & Odds Ratio \\
\hline
\end{tabular}

\section{Use of the Guidelines}

\section{Problem and aims}

The Austrian Urogynecology Working Group (Österreichische Arbeitsgemeinschaft für Urogynäkologie und Rekonstruktive Beckenbodenchirurgie [AUB]) formulated guidelines for the management of perineal tears (PT) of the 3rd and 4th degree after vaginal birth for the first time in 2007 . The various methods of surgical management had previously not been summarised systematically although use of inappropriate procedures could have serious consequences for the patients. 
By means of, in particular, recommendations on the diagnostics, therapy and follow-up in cases of higher degree perineal tears in the course of vaginal births these guidelines are intended to improve the management of such situations and to reduce their short- and long-term consequences. The guidelines are intended for midwives, physicians involved in obstetrics and also those confronted with the management of higher degree perineal tears. An update of the Austrian guidelines has now been undertaken in cooperation with the German Society for Gynaecology and Obstetrics (Deutsche Gesellschaft für Gynäkologie und Geburtshilfe DGGG) and, respectively the Consortium for Urogynaecology and Plastic Pelvic Floor Reconstruction (Arbeitsgemeinschaft für Urogynäkologie und Plastische Beckenbodenrekonstruktion [AGUB]).

\section{Addressees}

These guidelines are intended for the following target groups:

- practicing obstetricians/gynecologists

- obstetricians/gynecologists in hospitals

$\checkmark$ midwives

coloproctologists

\section{Background}

For the first time in 2007 the AUB Austria commissioned representatives of AUB Austria as well as coloproctologist colleagues of the ÖGC to prepare evidence- and consensus-based guidelines. These guidelines were adopted by the Austrian Society for Gynaecology and Obstetrics (Österreichische Gesellschaft für Gynäkologie und Geburtshilfe [OEGGG]). The first update was published in 2011, again evidence- and consensus-based, in cooperation with members of AUB Austria, ÖGC and the Austrian Midwives Committee (Österreichisches Hebammengremium). This update was again adopted by OEGGG. Furthermore, an English translation of the guidelines was published after the usual peer review process in the International Urogynecology Journal (Int Urogynecol J 2013; 24: 553-558).

The recently planned updated guidelines 2014 were again initiated by AUB Austria in cooperation with members of the AGUB Germany with the aim to produce common German language guidelines to be positioned as AWMF guidelines.

For literature searches and the preparation of suggestions for correction of the individual chapters the following colleagues with expert relevant knowledge were assigned as follows by the guideline coordinator ( $\bullet$ Table 5 ):

Table 5 Chapter topic.

\begin{tabular}{ll} 
Epidemiology & Tammaa, van der Kleyn \\
\hline Classification & Umek, Aigmüller \\
\hline Diagnostics & Elenskaia, Kölle \\
\hline Postpartum management & $\begin{array}{l}\text { Helmer, Pfeifer, Kropshofer, } \\
\text { Beilecke, Reisenauer }\end{array}$ \\
\hline Measures for postpartum inpatient period & Aigmüller, Frudinger \\
\hline Follow-up & Frudinger, Tamussino \\
\hline Recommendations for subsequent births & Huemer, Helmer, Elenskaia
\end{tabular}

On the basis of the literature searches for the present Austrian guidelines, publications on the management of higher degree perineal tears in English and German that appeared between November 2011 and January 2014 were considered. Searches were made in the databases PubMed and MEDLINE. The secondary literature was also taken into account.
The subject-related coordination was realised each time by means of a round mailing process. Coordination and formulation of the final version were carried out by Dr. Thomas Aigmüller as agent and guideline delegate of AUB and Prof. Werner Bader as agent of AGUB and guideline coordinator.

All authors have declared any conflicts of interest and these are summarised in tabular form in the Appendix. The conflict of interest declarations were obtained with the help of a standard AWMF form. The original completed forms have been deposited with the guideline coordinator. Self-assessments of the details were performed. Members of the guideline group who had received fees for lecturing activities (item 2 of the declaration) or financial support for research projects (item 3 of the declaration) received this support solely from companies that did not produce materials for the production of suture materials. The same was true for advisor or expert consultant activities (item 1 of the declaration) and for the possession of business interests, shares, and stocks with participation in companies in the health-care business (item 5 of the declaration). No participant was excluded from a vote for such a reason.

\section{Period of validity}

The validity of these guidelines was confirmed by the board of the DGGG and the DGGG guideline commission in October 2014. These guidelines have a validity period from 02.10 .2014 to 02.10.2017. This period has been estimated on the basis of content connections. If urgently needed, the guidelines may be updated at an earlier point in time; also if they are still in compliance with the current states of knowledge, the validity period may be extended.

\section{Epidemiology \\ Incidence}

According to the Austrian Birth Registry 2011, in the course of vaginal deliveries the frequency of 3rd degree perineal tears was $1.5 \%$ and that of 4 th degree tears $0.1 \%$ whereby the incidence of such tears in first-time mothers amounted to $1.8 \%$ and in multiparous women to $0.9 \%$ [1]. In Germany in 2012 the incidences were $0.95 \%$ ( 3 rd degree tears) and $0.09 \%$ (4th degree tears), data on the incidences for first-time mothers and multiparous women are not available [2].

In contrast, the incidence of lesions of the external or internal anal sphincter muscles was stated to be $11 \%$ in a systematic review [3].

In the past few years in general, an increasing incidence of higher grade perineal tears has been reported which is mainly due to an improved rate of detection [4].

Consecutive complaints include flatus incontinence, pathological stool urgency and, although less common, also incontinence for liquid or solid faeces. The frequency of these complaints increases continuously in the years following delivery [5-7].

\section{Risk factors}

In descending order of importance, in parentheses the odds ratio (OR) according to refs. [8-16,71]:

- birth weight $>4 \mathrm{~kg}$ (OR: 5.0 ; increasing with increasing birth weight of the baby)

- forceps (OR: 2.6-3.7)

- median episiotomy (OR: 2.4-2.9)

- nulliparous (OR: 2.4)

- shoulder dystocia (OR: 2.0)

- delivery in lithotomy or deep squatting position (OR: 2.0) 
- Kristeller's manoeuvre/fundal pressure (OR: 1.8)

- vacuum extraction (OR: 1.7-2.6)

- prolonged second stage of labor:

- nulliparous without epidural anaesthesia, second stage of labor $>2$ h (OR 1.78)

- nulliparous with epidural anaesthesia, second stage of labor $>3 \mathrm{~h}(\mathrm{OR} 1.80)$

- multiparous without epidural anaesthesia, second stage of labor $>1 \mathrm{~h}(\mathrm{OR} 3.2)$

$\checkmark$ multiparous with epidural anaesthesia, second stage of labor $>2 \mathrm{~h}$ (OR 3.85)

- family risk - sister or mother with 3rd or 4th degree perineal tears (OR 1.7 or, respectively, 1.9)

- occipitoposterior position (OR: 1.7)

- male baby (OR 1.3)

\section{Risk reducing factors}

- lateral episiotomy in vacuum extraction (OR 0.6) [17,18]

- women with nicotine abuse have a lower risk for a higher degree perineal tear (OR 0.72 at the first birth) [20]

The following obstetric measures are neither prophylactic nor do they increase the risk for higher degree perineal tears $[8,11,21-25]$ :

- antenatal or subpartal perineal massage

- water birth

- augmentation of contractions

- time and type of pushing

- Ritgen's manoeuvre

- EPI-NO ${ }^{\circledR}$

The following obstetric factors/measures cannot be conclusively evaluated on account of inadequate or contradictory data:

- peridural anaesthesia $[11,15,17,26,73]$

- "Hands on" on the perineum $[74,75]$

- perineal subpartal moist compression [23]

- maternal obesity $[19,17,72]$

- induction of labour $[3,17,76]$

The evidence for episiotomy as a prophylaxis against higher degree perineal tears is divergent $[8,26,27]$. Median episiotomy is consistently associated with an increased risk for higher degree perineal tears. Mediolateral episiotomy should be used restrictively $[28,29]$.

\section{Classification}

A higher degree perineal tear is present when at least the external anal sphincter muscle is injured [30]:

- 3rd degree perineal tear: anal sphincter injured, anorectal epithelium intact

- 4th degree perineal tear: sphincter injured, anorectal epithelium torn

The following subdivision of 3rd degree perineal tears can be useful [31]:

- IIIa... less than $50 \%$ of the thickness of the external anal sphincter muscle torn

- IIIb... more than $50 \%$ of the thickness of the external anal sphincter muscle torn

- IIIc... external and internal anal sphincter muscles torn

Since the internal anal sphincter plays an important part in the continence mechanism attempts should be made to identify it in cases of extensive injuries $[32,33]$.
A special form of higher degree perineal tear is a laceration of the anorectal epithelium with intact external anal sphincter muscle ("buttonhole tear"). This is very rare but, when not treated, carries the risk of a rectovaginal fistula and can be diagnosed by anal palpation in the postpartum period [34-36]. In cases with laceration of the anal skin and intact external anal sphincter muscle, there is an increased probability of injury to the internal anal sphincter. Conclusive clarification of this type of defect is only possible by surgery or endosonography $[77,78]$.

\section{Diagnostics}

After vaginal birth a 3rd or 4th degree perineal tear must first be excluded by careful inspection and/or palpation by the obstetrician and/or midwife. Not only vaginal but also anorectal palpation for the assessment of birth injuries is extremely important. In cases of at least a 2 nd degree perineal tear both vaginal and rectal palpations are recommended to assess the extent of the injury.

If a 3rd or 4th degree perineal tear cannot be excluded, an experienced physician with special knowledge (preferably a specialist for gynaecology and obstetrics or a consultant with coloproctological expertise) should be called in to check the diagnosis, and, if necessary, to make a provisional, orienting classification (3rd or 4th degree) and initiate the further steps.

\section{$4 \quad$ Postpartum management \\ Preparation}

Management of 3rd or 4th degree perineal tears requires general or regional anaesthesia in order to achieve a maximal sphincter relaxation and a sufficient pain relief. The procedure is done under aseptic conditions in an operating room or equivalent facility with assistants, appropriate instruments and equipment. The patient is placed in the lithotomy position. The operating team should include a specialist with adequate experience [37]. The number of previous operations, however, does not seem to be relevant with regard to the avoidance of anal incontinence [38].

In exceptional cases the operation may be delayed for up to 12 hours post-partum [39].

With the exception of emergency situations an adequate and documented preoperative informed consent is essential.

A preoperative prophylactic antibiotic therapy (e.g., with 2nd generation cephalosporins) should be administered [40].

\section{Surgical strategy}

I. Identification of additional birth injuries and exact classification of the perineal tear by means of speculum inspection and digital rectal examination.

II. If necessary first management of cervical and high vaginal tears (from the top down), and then management of the perineal tear.

III. For 4th degree tears: repair anorectal epithelium with atraumatic, 3-0, end-to-end sutures $[41,42]$.

IV. If the edges of the torn internal anal sphincter can be identified approximate the edges with atraumatic interrupted mattress sutures, preferably 3-0 $[42,43]$.

$\mathrm{V}$. Identification of the edges of the external anal sphincter muscle and gripping them with Allis clamps.

VI. Suture of the external anal sphincter muscle with atraumatic U sutures - preferably with thread size $2-0$. There is a choice between two methods: the overlapping technique and the end-to-end technique [46-48]. For an incomplete tear of 
the muscle, the end-to-end technique should be used [38, 44 ]. Use of the overlapping technique reduces the symptoms of stool urgency and stool incontinence after 1 year whereas, after 3 years, no differences between the two techniques can be found [45]. There are hints that the rate of flatulence is reduced with the end-to-end technique [44]. A conclusive recommendation for one method or the other cannot be given. The surgeon should choose that method with which he/ she has more experience.

VII. Layer-by-layer management of the perineum.

VIII. Documentation of birth injuries and surgical report.

For items III-VI atraumatic, slowly resorbable suture material should be used. The choice between braided and monofilament material is left to the surgeon's individual preference [43,46-48]. A prophylactic bowel stoma is not indicated $[49,50]$ ( $\bullet$ Figs. 1 to 3).

\section{$5 \quad$ Puerperium}

\section{Antibiotics}

There is no evidence for the postoperative prophylactic administration of antibiotics. Because of the contaminated wound situation as well as the possibly severe consequences of a wound infection (through to a necessary bowel stoma), the authors of the guidelines consensually recommend the prophylactic administration of antibiotics [31].

\section{Laxatives}

The prophylactic administration of lactulose reduces the pain on first bowel movements after management of a higher degree perineal tear. Postoperative pain, rate of wound infections, continence and dyspareunia are not affected by the administration of laxatives. Furthermore, administration of laxatives for a few days is recommended in order to reduce the mechanical stress on the sutures [51].

In cases with uncomplicated healing processes, rectal examinations should be omitted [43].

The rate of wound complications after 3rd and 4th degree perineal tears (wound infection, dehiscence, reoperation, readmis-

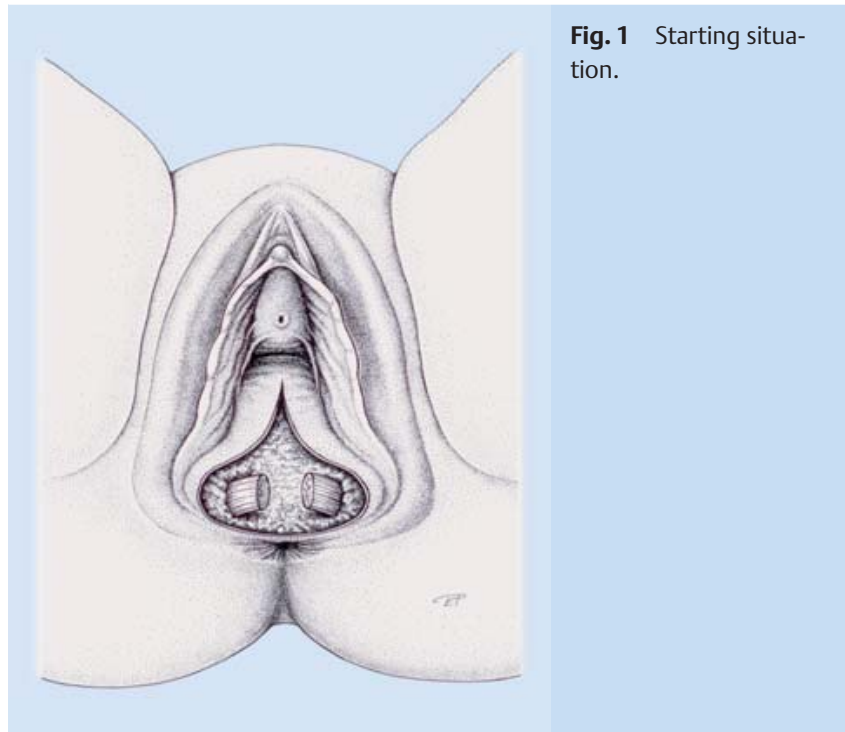

sion to hospital) amounts to $7.3 \%$, whereby smoking and a higher BMI represent independent risk factors [52].

The patients should be informed about the extent of birth injuries and possible late sequelae. Information about follow-up, behavioural actions and contact details in case of problems should be given.

\section{Follow-up}

A gynaecological follow-up examination should be scheduled at about 3 months post-partum. This follow-up examination should at least include the following items:

- history of symptoms of anal incontinence [46, 48, 53-56]

- flatus incontinence (up to $50 \%$ )

- defaecatory urgency (26\%)

- incontinence for liquid stool (8\%)

- incontinence for solid stool (4\%)

- inspection of the perineum

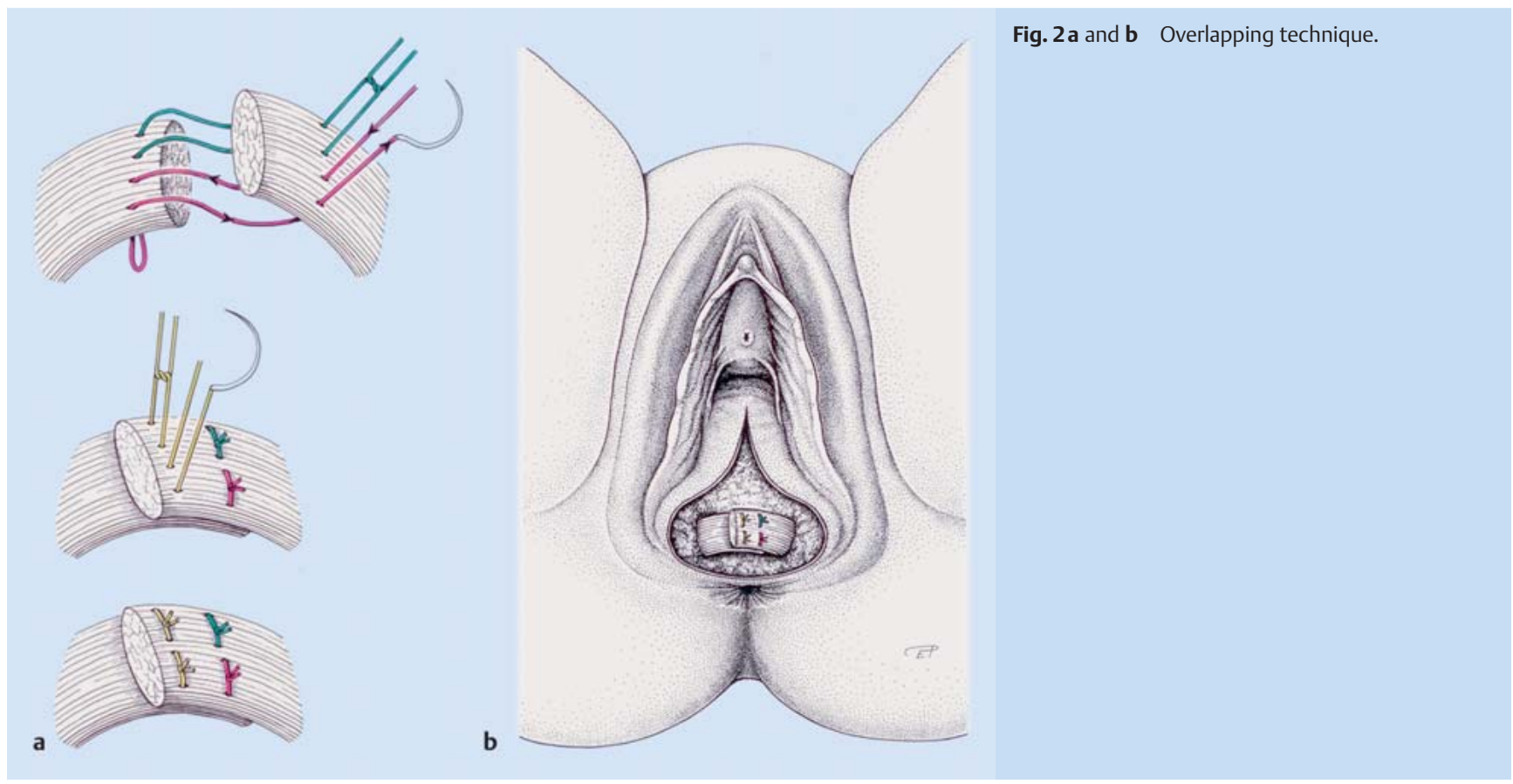




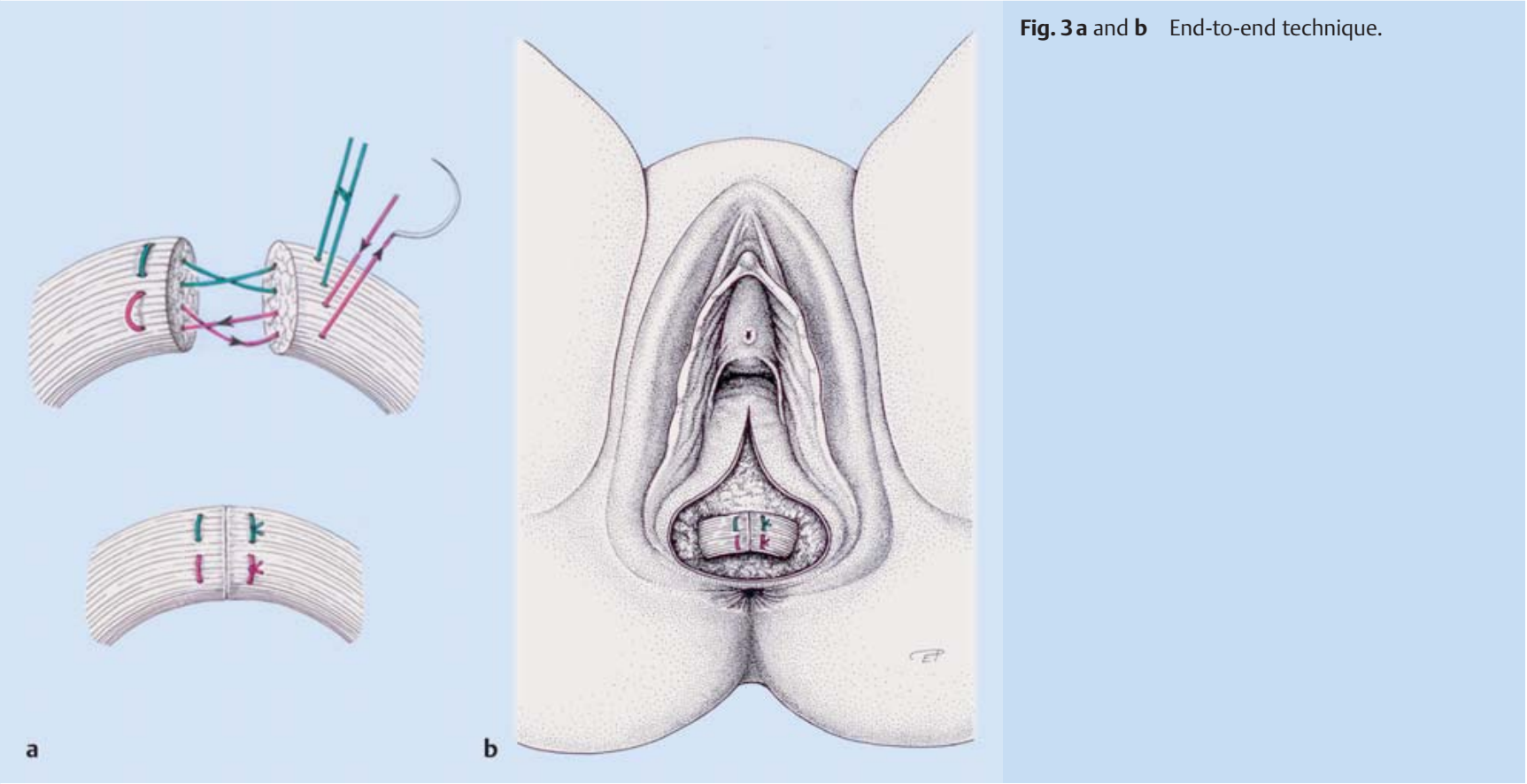

- vaginal and rectal palpation

- Referral to physiotherapy for the purpose of strengthening the pelvic floor musculature. Early biofeedback-supported physiotherapy has no advantage over classical pelvic floor training [57]. For anal incontinence, the so-called triple-target therapy (combination of amplitude-modulated medium frequency stimulation and electromyographic biofeedback) is superior to a standard stimulation therapy with electromyographic biofeedback [58].

- Information about a possibly long latency onset/worsening of the symptoms of anal incontinence $[59,60]$.

- discussion regarding subsequent pregnancies and births

- In cases of anal incontinence, referral of the patient to a centre with the appropriate expertise (anal endosonography, conservative as well as surgical therapeutic options) is recommended.

\section{Recommendations for subsequent deliveries}

The available data do not allow any recommendations as to the birth mode for future pregnancies. The patient should be informed that in a subsequent vaginal birth the risk for a renewed injury to the anal sphincter muscles can be, depending on the data source, non-existent $[38,44,45]$ or up to 7 -fold increased [6165]; however, more than $95 \%$ of the women do not suffer from a further higher degree perineal tear $[63,66]$. In addition, the risk increases with increasing birth weight of the baby [61-66]. Similarly it has been shown for the vaginal birth mode after 3rd/4th degree perineal tears that the short-term risk for persisting anal incontinence is increased $[67,68]$. In long-term studies over a period of 5 or more years this difference is no longer apparent [69, 70].

An elective Caesarean section should be offered to all women who have previously suffered from 3rd/4th degree perineal tears, and especially to those patients with

- persisting fecal incontinence,

- reduced sphincter function or

- suspected fetal macrosomia.

Also for vaginal births in patients with prior 3rd/4th degree perineal tears, an episiotomy should be used restrictively [66].

\section{Affiliations}

${ }^{1}$ Universitätsklinik für Frauenheilkunde und Geburtshilfe Graz, Österreich

${ }^{2}$ Klinikum Bielefeld, Bielefeld

${ }^{3}$ Klinik St. Hedwig, KH Barmherzige Brüder, Regensburg

${ }^{4}$ Medizinische Universität Wien, Wien, Österreich

${ }^{5}$ Klinikum Wels-Grieskirchen, Österreich

${ }^{6} \mathrm{FH}$ Joanneum, Graz, Österreich

7 Spital Region Oberaargau/Langenthal

${ }^{8}$ Medizinische Universität Innsbruck, Innsbruck, Österreich

${ }^{9}$ Universitätsklinikum Tübingen, Tübingen

${ }^{10}$ Wilhelminenspital Wien, Wien, Österreich

\section{References}

1 Oberaigner W, Leitner H, Kölle D. Geburtenregister Tirol - Bericht über die Geburtshilfe in Tirol 2010. Innsbruck: Eigenverlag; 2011

2 Statistisches Bundesamt Deutschland. Gesundheitsberichterstattung des Bundes. Online: www.gbe-bund.de/oowa921-in-stall/servlet/ oowa/aw92/WS0100/_XWD_FORMPROC?TARGET =\&PAGE=_XWD_ $106 \& O P I N D E X=3 \& H A N D L E R=\_X W D \_C U B E . S E T P G S \& D A T A C U B E=$ XWD_134\&D.001=1000001\&D.946=32202; Stand: 10.05 .2014

3 Dudding TC, Vaizey CJ, Kamm MA. Obstetric anal sphincter injury: incidence, risk factors, and management. Ann Surg 2008; 247: 224-237

4 Gurol-Urganci I, Cromwell DA, Edozien LC et al. Third- and fourth-degree perineal tears among primiparous women in England between 2000 and 2012: time trends and risk factors. BJOG 2013; 120: 15161525

5 Pollack J, Nordenstam J, Brismar S et al. Anal incontinence after vaginal delivery: a five-year prospective cohort study. Obstet Gynecol 2004; 104: $1397-1402$

6 Nordenstam J, Altman D, Brismar S et al. Natural progression of anal incontinence after child-birth. Int Urogynecol J Pelvic Floor Dysfunct 2009; 20: 1029-1035

7 Frudinger A, Ballon M, Taylor SA et al. The natural history of clinically unrecognized anal sphincter tears over 10 years after first vaginal delivery. Obstet Gynecol 2008; 111: 1058-1064

8 de Leeuw JW, Struijk PC, Vierhout ME et al. Risk factors for third degree perineal ruptures during delivery. BJOG 2001; 108: 383-387

9 Gottvall K, Allebeck P, Ekéus C. Risk factors for anal sphincter tears: the importance of maternal position at birth. BJOG 2007; 114: 1266-1272

10 Lowder JL, Burrows LJ, Krohn MA et al. Risk factors for primary and subsequent anal sphincter lacerations: a comparison of cohorts by parity and prior mode of delivery. Am J Obstet Gynecol 2007; 196: 344.e1344.e5

11 Landy HJ, Laughon SK, Bailit JL et al. Characteristics associated with severe perineal and cervical lacerations during vaginal delivery. Obstet Gynecol 2011; 117: 627-635 
12 Groutz A, Hasson J, Wengier A et al. Third- and fourth-degree perineal tears: prevalence and risk factors in the third millennium. Am J Obstet Gynecol 2011; 204: 347.e1-347.e4

13 Sultan AH, Kamm MA, Hudson $C N$ et al. Third degree obstetric anal sphincter tears: risk factors and outcome of primary repair. BM] 1994; 308: 887-891

14 Baghestan E, Irgens LM, Børdahl PE et al. Familial risk of obstetric anal sphincter injuries: registry-based cohort study. BJOG 2013; 120: 831837

15 Smith LA, Price N, Simonite Vet al. Incidence of and risk factors for perineal trauma: a prospective observational study. BMC Pregnancy Childbirth 2013; 13: 59

16 Dahlen H, Priddis H, Schmied V et al. Trends and risk factors for severe perineal trauma during childbirth in New South Wales between 2000 and 2008: a population-based data study. BMJ Open 2013; 3: e002824

17 Jangö H, Langhoff-Roos J, Rosthøj S et al. Modifiable risk factors of obstetric anal sphincter injury in primiparous women: a populationbased cohort study. Am J Obstet Gynecol 2014; 210: 59.e1-59.e6

18 Ampt AJ, Ford JB, Roberts CL et al. Trends in obstetric anal sphincter injuries and associated risk factors for vaginal singleton term births in New South Wales 2001-2009. Aust N Z J Obstet Gynaecol 2013; 53: 9-16

19 Lindholm ES, Altman D. Risk of obstetric anal sphincter lacerations among obese women. BJOG 2013; 120: 1110-1115

20 Räisänen S, Cartwright R, Gissler M et al. The burden of OASIS increases along with socioeconomic position-register-based analysis of 980,733 births in Finland. PLoS One 2013; 8: e73515

21 Mei-dan E, Walfisch A, Raz I et al. Perineal massage during pregnancy: a prospective controlled trial. Isr Med Assoc J 2008; 10: 499-502

22 Beckmann MM, Stock OM. Antenatal perineal massage for reducing perineal trauma. Cochrane Database Syst Rev 2013; 4: CD005123

23 Aasheim $V$, Nilsen $A B$, Lukasse $M$ et al. Perineal techniques during the second stage of labour for reducing perineal trauma. Cochrane Database Syst Rev 2011; 12: CD006672

24 Ruckhäberle E, Jundt K, Bäuerle $M$ et al. Prospective randomised multicentre trial with the birth trainer EPI-NO for the prevention of perineal trauma. Aust N Z J Obstet Gynaecol 2009; 49: 478-483

25 Shek KL, Chantarasorn V, Langer $S$ et al. Does the Epi-No ${ }^{\circledR}$ Birth Trainer reduce levator trauma? A randomised controlled trial. Int Urogynecol J 2011; 22: 1521-1528

26 Eskandar 0 , Shet $D$. Risk factors for 3rd and 4th degree perineal tear J Obstet Gynaecol 2009; 29: 119-122

27 Baumann P, Hammoud AO, McNeeley SG et al. Factors associated with anal sphincter laceration in 40,923 primiparous women. Int Urogynecol J Pelvic Floor Dysfunct 2007; 18: 985-990

28 Carroli G, Mignini L. Episiotomy for vaginal birth. Cochrane Database Syst Rev 2009; 1: CD000081

29 Murphy DJ, Macleod M, Bahl R et al. A randomised controlled trial of routine versus restrictive use of episiotomy at operative vaginal delivery: a multicentre pilot study. BJOG 2008; 115: 1695-1702

30 Cunningham FG, Leveno KJ, Bloom SL, Hauth JC, Rouse DJ, Spong CY, eds. Williams Obstetrics. 23rd ed. New York: McGraw-Hill; 2009

31 Royal College of Obstetricians and Gynaecologists. Guideline No. 29, Clinical Green Top Guidelines: Management of third- and fourth-degree perineal tears following vaginal delivery - March 2007. Online: www.rcog.org.uk/guidelines; last access: 26.02.2015

32 Lindqvist PG, Jernetz $M$. A modified surgical approach to women with obstetric anal sphincter tears by separate suturing of external and internal anal sphincter. A modified approach to obstetric anal sphincter injury. BMC Pregnancy Childbirth 2010; 10: 51

33 Mahony R, Behan M, Daly L et al. Internal anal sphincter defect influences continence outcome following obstetric anal sphincter injury. Am J Obstet Gynecol 2007; 196: 217.e1-217.e5

34 Rieger N, Perera S, Stephens J et al. Anal sphincter function and integrity after primary repair of third-degree tear: uncontrolled prospective analysis. ANZ J Surg 2004; 74: 122-124

35 Chew SS, Rieger NA. Transperineal repair of obstetric-related anovaginal fistula. Aust N Z J Obstet Gynaecol 2004; 44: 68-71

36 Rahman MS, Al-Suleiman SA, El-Yahia AR et al. Surgical treatment of rectovaginal fistula of obstetric origin: a review of 15 years' experience in a teaching hospital. J Obstet Gynaecol 2003; 23: 607-610

37 Sultan $A H$. Primary and secondary anal Sphincter Repair. In: Stanton SL, Zimmern PE, eds. Female pelvic reconstructive Surgery. London: Springer; 2003: 149-157
38 Scheer I, Thakar R, Sultan AH. Mode of delivery after previous obstetric anal sphincter injuries (OASIS)-a reappraisal? Int Urogynecol J Pelvic Floor Dysfunct 2009; 20:1095-1101

39 Nordenstam J, Mellgren A, Altman D et al. Immediate or delayed repair of obstetric anal sphincter tears - a randomised controlled trial. BJOG 2008; 115: 857-865

40 Duggal N, Mercado C, Daniels K et al. Antibiotic prophylaxis for prevention of post-partum perineal wound complications: a randomized controlled trial. Obstet Gynecol 2008; 111: 1268-1273

41 Briel JW, de Boer LM, Hop WCJ et al. Clinical outcome of anterior overlapping external anal sphincter repair with internal anal sphincter imbrication. Dis Colon Rectum 1998; 41: 209-214

42 Thakar R, Sultan AH. Management of obstetric anal sphincter injury. Obstet Gynecol 2003; 5: 72-78

43 Sultan AH, Monga AK, Kumar D et al. Primary repair of obstetric anal sphincter rupture using the overlap technique. Br J Obstet Gynaecol 1999; 106: 318-323

44 Priddis H, Dahlen HG, Schmied V et al. Risk of recurrence, subsequent mode of birth and morbidity for women who experienced severe perineal trauma in a first birth in New South Wales between 2000-2008: a population based data linkage study. BMC Pregnancy Childbirth 2013; 13: 89

45 Edwards $\mathrm{H}$, Grotegut C, Harmanli $\mathrm{OH}$ et al. Is severe perineal damage increased in women with prior anal sphincter injury? J Matern Fetal Neonatal Med 2006; 13: 723-727

46 Fernando RJ, Sultan AH et al. Repair techniques for obstetric anal sphincter injuries: a randomised controlled trial. Obstet Gynecol 2006; 107: 1261-1268

47 Fernando R, Sultan A, Kettle C et al. Methods of repair for obstetric anal sphincter injury. Cochrane Database Syst Rev 2013; 12: CD002866

48 Farrell SA, Gilmour D, Turnbull GK et al. Overlapping compared with end-to-end repair of third- and fourth-degree obstetric anal sphincter tears: a randomized controlled trial. Obstet Gynecol 2010; 116: 16-24

49 Hasegawa H, Yoshioka K, Keighley MR. Randomized trial of fecal diversion for sphincter repair. Dis Colon Rectum 2000; 43: 961-964; discussion 964-965

50 Clark CL, Wilkinson KH, Rihani HR et al. Peri-operative management of patients having external anal sphincter repairs: temporary prevention of defaecation does not improve outcomes. Colorectal Dis 2001; 3 : 238-244

51 Mahony R, Behan M, O'Herlihy C et al. Randomized, clinical trial of bowel confinement versus laxative use after primary repair of a third-degree obstetric anal sphincter tear. Dis Colon Rectum 2004; 47: 12-17

52 Stock L, Basham E, Gossett DR et al. Factors associated with wound complications in women with obstetric anal sphincter injuries (OASIS). Am J Obstet Gynecol 2013; 208: 327.e1-327.e6

53 Williams A, Adams EJ, Tincello DG et al. How to repair an anal sphincter injury after vaginal delivery: results of a randomised controlled trial. BJOG 2006; 113: 201-207

54 Garcia V, Rogers RG, Kim SS et al. Primary repair of obstetric anal sphincter laceration: a randomized trial of two surgical techniques. Am J Obstet Gynecol 2005; 192: 1697-1701

55 Malouf AJ, Norton CS, Engel AF et al. Longterm results of overlapping anterior anal sphincter repair for obstetric trauma. Lancet 2000; 355: 260-265

56 Fitzpatrick $M$, Behan $M$, O'Connell $R$ et al. A randomised clinical trial comparing primary overlap with approximation repair of third degree tears. Am J Obstet Gynaecol 2000; 183: 1220-1224

57 Peirce C, Murphy C, Fitzpatrick $M$ et al. Randomised controlled trial comparing early home biofeedback physiotherapy with pelvic floor exercises for the treatment of third-degree tears (EBAPT Trial). BJOG 2013; 120: 1240-1247; discussion 1246

58 Schwandner T, König IR, Heimerl T et al. Triple target treatment (3T) is more effective than biofeedback alone for anal incontinence: the 3T-AI study. Dis Colon Rectum 2010; 53:1007-1016

59 Poen AC, Felt-Bersma RJ, Dekker GA et al. Third degree obstetric perineal tears: risk factors and the preventative role of mediolateral episiotomy. BJOG 1997; 104: 563-566

60 Frudinger A, Ballon M, Taylor SA et al. The natural history of clinically unrecognized anal sphincter tears over 10 years after first vaginal delivery. Obstet Gynecol 2008; 111: 1058-1064

61 Peleg D, Kennedy CM, Merrill D et al. Risk of repetition of a severe perineal laceration. Obstet Gynecol 1999; 93: 1021

62 Payne TN, Carey JC, Rayburn WF. Prior third- or fourth-degree perineal tears and recurrence risks. Int J Gynaecol Obstet 1999; 64: 55 
63 Harkin R, Fitzpatrick M, O'Connell PR et al. Anal sphincter disruption at vaginal delivery: is recurrence predictable? Eur J Obstet Gynecol Reprod Biol 2003; 109: 149

64 Elfaghi I, Johansson-Ernste B, Rydhstroem $H$. Rupture of the sphincter ani: the recurrence rate in second delivery. BJOG 2004; 111: 1361

65 Baghestan E, Irgens LM, Børdahl PE et al. Risk of recurrence and subsequent delivery after obstetric anal sphincter injuries. BJOG 2012; 119 : 62-69

66 Basham E, Stock L, Lewicky-Gaupp C et al. Subsequent pregnancy outcomes after obstetric anal sphincter injuries (OASIS). Female Pelvic Med Reconstr Surg 2013; 19: 328-332

67 Bek KM, Laurberg S. Risks of anal incontinence from subsequent vaginal delivery after a complete obstetric anal sphincter tear. Br J Obstet Gynaecol 1992; 99: 724-726

68 Fynes $M$, Donnelly V, Behan $M$ et al. Effect of second vaginal delivery on anorectal physiology and faecal continence: a prospective study. Lancet 1999; 354: 983-986

69 Faltin DL, Otero M, Petignat $P$ et al. Women's health 18 years after rupture of the anal sphincter during childbirth: I. Fecal incontinence. Am J Obstet Gynecol 2006; 194: 1255-1259

70 Sze EH. Anal incontinence among women with one versus two complete third-degree perineal lacerations. Int J Gynaecol Obstet 2005; 90: 213-217

71 Laughon KS, Berghella V, Reddy UM et al. Neonatal and maternal outcomes with prolonged second stage of labor. Obstet Gynecol 2014; 124: 57-67

72 Blomberg $M$. Maternal body mass index and risk of obstetric anal sphincter injury. Biomed Res Int 2014; 2014: 395803

73 Dahlen HG, Ryan M, Homer CS et al. An Australian prospective cohort study of risk factors for severe perineal trauma during childbirth. Midwifery 2007; 23: 196-203

74 Samuelsson E, Ladfors L, Wennerholm UB et al. Anal sphincter tears: prospective study of obstetric risk factors. BJOG 2000; 107: 926-931
75 Kettle C, Tohill S. Perineal care. Clin Evid (Online) 2011; 2011: pii: 1401

76 Baghestan E, Irgens LM, Børdahl PE et al. Trends in risk factors for obstetric anal sphincter injuries in Norway. Obstet Gynecol 2010; 116: 25-34

77 Burnett SJ, Spence-Jones C, Speakman CT et al. Unsuspected sphincter damage following childbirth revealed by anal endosonography. $\mathrm{Br}$ J Radiol 1991; 64: 225-227

78 Blatchford GJ, Rivela LJ, Lin K et al. Diagnosing anal sphincter injury with transanal ultrasound and manometry. Dis Colon Rectum 1997; 40: $1430-1434$

The "guidelines" of the Scientific Medical Professional Societies (Wissenschaftliche Medizinische Fachgesellschaften) are systematically developed aids for the physician in decision-making for specific situations. They are based on current scientific knowledge and practically established procedures and thus serve to provide more safety in medicine while also taking economic aspects into consideration. The "guidelines" are not legally binding for physicians and thus provide neither a basis for liability claims nor for a freedom from liability. The AWMF compiles and publishes the guidelines of the professional societies with the greatest possible care - even so the AWMF cannot accept any responsibility for the correctness of the contents. Especially in the case of dosages, the details provided by the respective manufacturer should always be consulted!

(C) German Society for Gynaecology and Obstetrics (Deutsche Gesellschaft für Gynäkologie und Geburtshilfe)

\section{Authorised for electronic publication: AWMF online}

\begin{tabular}{|c|c|}
\hline Homepage & http://www.awmf.org/leitlinien/detail/II/015-079.html \\
\hline Date of publication & 02.10 .2014 \\
\hline Next assessment planned & 02.10 .2017 \\
\hline $\begin{array}{l}\text { Declarations of conflicts of } \\
\text { interest }\end{array}$ & available on the AWMF homepage under: http://www.awmf.org/leitlinien/detail/II/015-079.html \\
\hline \multirow[t]{14}{*}{$\begin{array}{l}\text { Participating professional } \\
\text { societies and organisations: }\end{array}$} & $\begin{array}{l}\text { German Society for Gynaecology and Obstetrics (Deutsche Gesellschaft für Gynäkologie und Geburtshilfe [DGGG] e. V.) } \\
\text { (responsible) }\end{array}$ \\
\hline & - Scientific and Medical Professional Societies (Wissenschaftlichen Medizinischen Fachgesellschaften e. V. [AWMF]) \\
\hline & $\begin{array}{l}\text { Consortium for Urogynaecology and Plastic Pelvic Floor Reconstruction } \\
\text { (Arbeitsgemeinschaft für Urogynäkologie und plastische Beckenbodenrekonstruktion AGUB) }\end{array}$ \\
\hline & $\begin{array}{l}\text { Austrian Urogynecology Working Group } \\
\text { (Österreichische Arbeitsgemeinschaft für Urogynäkologie und Rekonstruktive Beckenbodenchirurgie [AUB]) }\end{array}$ \\
\hline & - German Society for Midwife Science (Deutsche Gesellschaft für Hebammenwissenschaft) \\
\hline & - Consortium for Materno-Foetal Medicine (Arbeitsgemeinschaft für materno-fetale Medizin e. V. [AGMFM]) \\
\hline & - Consortium for Medical Rights of the DGGG (Arbeitsgemeinschaft Medizinrecht der DGGG [AGMedR[) \\
\hline & - Consortium for Hypetension in Pregnancy/Gestosis (Arbeitsgemeinschaft Schwangerschaftshochdruck/Gestose e. V.) \\
\hline & - German Society for Prenatal and Neonatal Medicine (Deutsche Gesellschaft für Pränatal- und Geburtsmedizin] \\
\hline & - Surgical Consortium for Coloproctology in Germany (Chirurgische Arbeitsgemeinschaft Coloproktologie Deutschland [CACP[) \\
\hline & - German Society for Coloproctology (Deutsche Gesellschaft für Koloproktologie [DGK]) \\
\hline & $\begin{array}{l}\text { Swiss Consortium for Urogynaecology and Pelvic Floor Pathology } \\
\text { (Schweizerische Arbeitsgemeinschaft für Urogynäkologie und Beckenbodenpathologie [AUG]) }\end{array}$ \\
\hline & - Consortium for Coloproctology in Austria (Arbeitsgemeinschaft für Coloproktologie Österreich [ACP[) \\
\hline & - Austrian Society for Gynaecology and Obstetrics (Österreichische Gesellschaft für Gynäkologie und Geburtshilfe [OEGGG[) \\
\hline
\end{tabular}

